\title{
Prevalence of Hyalomma aegyptium (Linneaus, 1758) on Tortoises (Testudo graeca) in Izmir and Aydin Province, Turkey
}

\author{
Serkan Bakirci \\ Adnan Menderes University, Faculty of Veterinary Medicine, Department of Parasitology
}

Geliş Tarihi / Received: 03.09.2015, Kabul Tarihi / Accepted: 10.02.2016

\begin{abstract}
In this study, a total of 228 adult ticks were collected from twelve tortoises between 07.05.2007 and 08.07.2008 in Izmir and Aydin, Turkey. All ticks were identified as Hyalomma aegyptium. The proportion of adult ticks collected from Izmir and Aydin provinces were 60,08\% $(\mathrm{n}=137)$ and 39,92\% $(\mathrm{n}=91)$, respectively.
\end{abstract}

Key words: Hyalomma aegyptium, ticks, tortoise, Turkey

\section{İzmir ve Aydın İlindeki Kaplumbağalarda Hyalomma aegyptium (Linneaus, 1758)'un Yaygınlığı}

\begin{abstract}
Özet: Bu çalışmada, 07.05.2007 ve 08.07.2008 tarihleri arasında İzmir ve Aydin illerinde yakalanan 12 kaplumbağadan toplam 228 adet erişkin kene toplanmıştır. Toplanan tüm keneler Hyalomma aegyptium olarak identifiye edilmiştir. İzmir ve Aydin illerinden toplanan kenelerin oranı sırasıyla \%60,08 (n=137) ve \%39,92 (n=91) olarak belirlenmiştir.
\end{abstract}

Anahtar kelimeler: Hyalomma aegyptium, kaplumbağa, kene, Türkiye

\section{Introduction}

Ticks are the most prominent vectors within pests after mosquitoes. The genus Hyalomma Koch, 1844, like all other tick species, are ectoparasites that feed on animals and humans and transmit a great variety of parasitic, ricketsial, bacterial and viral agents to both humans and animals including; Lyme disease, babesiosis, ehrlichiosis, tularemia, Crimean-Congo hemorrhagic fever $[7,16]$. There are 30 Hyalomma species known to exist throughout the world. The genus Hyalomma distributed in Asia, southern Europe and Africa $[8,14]$. Among these, nine spp. have been identified in Turkey: H. aegyptium, H. anatolicum, $H$. dromedarii, $H$. excavatum, $H$. impeltatum, $H$. marginatum, H. rufipes, $H$. scupense (syn $H$. detritum), H. turanicum [3,6,10].

Tortoises are known as the common hosts for adult H.aegyptium in the Mediterranean region, Balkan countries, Middle East, Central Asia, Northern Africa, Afghanistan and Pakistan $[1,17,18]$. The species Testudo graeca Linnaeus, 1758, is a tortoise inhabiting in Northern Africa, Middle East and Europe [16]. H.aegyptium is known as a three-host life cycle tick and infests tortoises, lizards, hedgehogs, birds, small mammals and even human. However, tortoises of the genus Testudo are the main hosts of adult H.aegyptium [1,6,18-20]. In this study, the ticks on T.graeca living in natural areas in Aydin and Izmir province were determined.

\section{Material and Methods}

This study was carried out between 07.05.2007 and 08.07.2008 on a total twelve tortoises found in Izmir and Aydin, Turkey (Figure 1). Tortoises were captured in forested areas, roadsides, vegetable gardens and all were inspected for the presence of ticks. Ticks were collected manually from alive tortoises and preserved in $70 \%$ ethanol for identification. All collected ticks were identified based on morphological differences of each species using the methods described by Hoogstraal [14] and Apanaskevich [1]. 


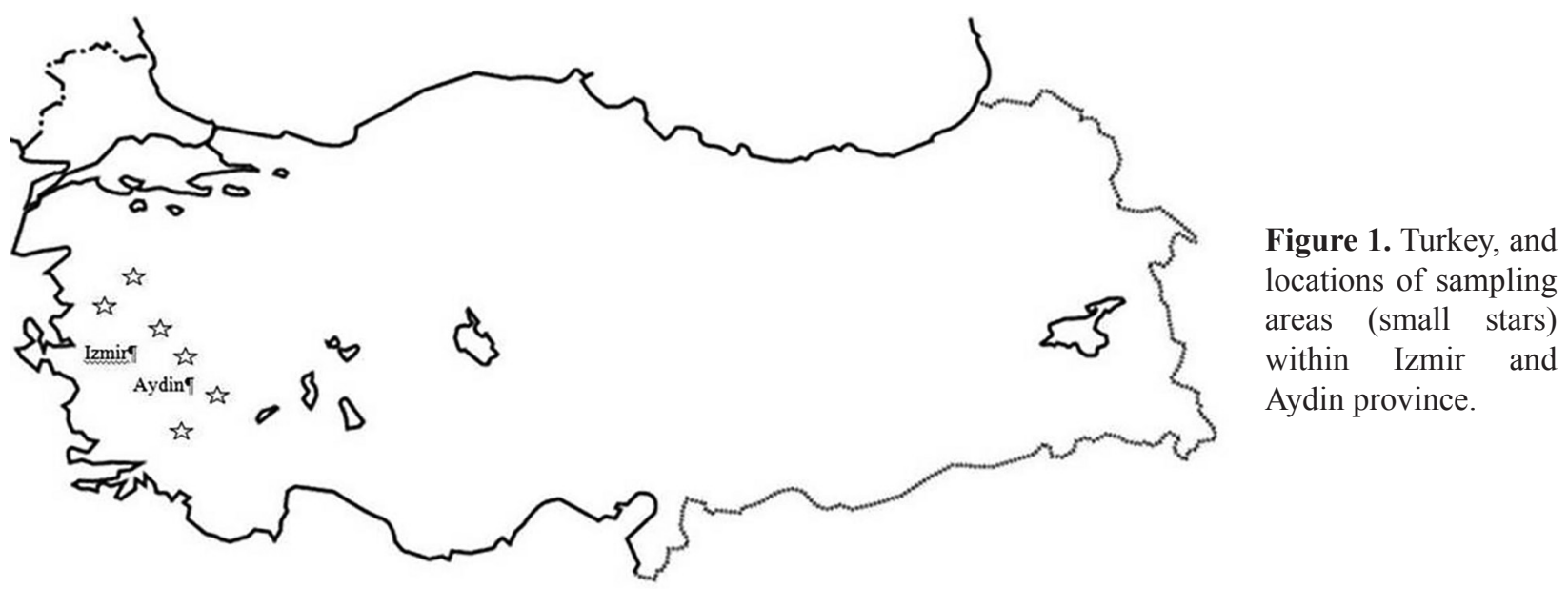

\section{Results}

During the study a total of 228 adult ticks were collected from tortoises. Attached ticks were found on the skin parts of hind legs and neck of tortoises. All collected ticks were identified as H.aegyptium (Figure 2). It was found that $147(64,47 \%)$ out of 228 identified ticks were male and $81(35,53 \%)$ out of 228 were found to be female (Table 1). The proportion of adult ticks collected from Izmir and Aydin provinces were $60,08 \%(\mathrm{n}=137)$ and $39,92 \%$ $(n=91)$, respectively (Table 1$)$. Evaluation of the distribution of ticks attached on a montly base indicated that infestation by H.aegyptium increased May - July with the highest numbers of attached occuring during the summer season.

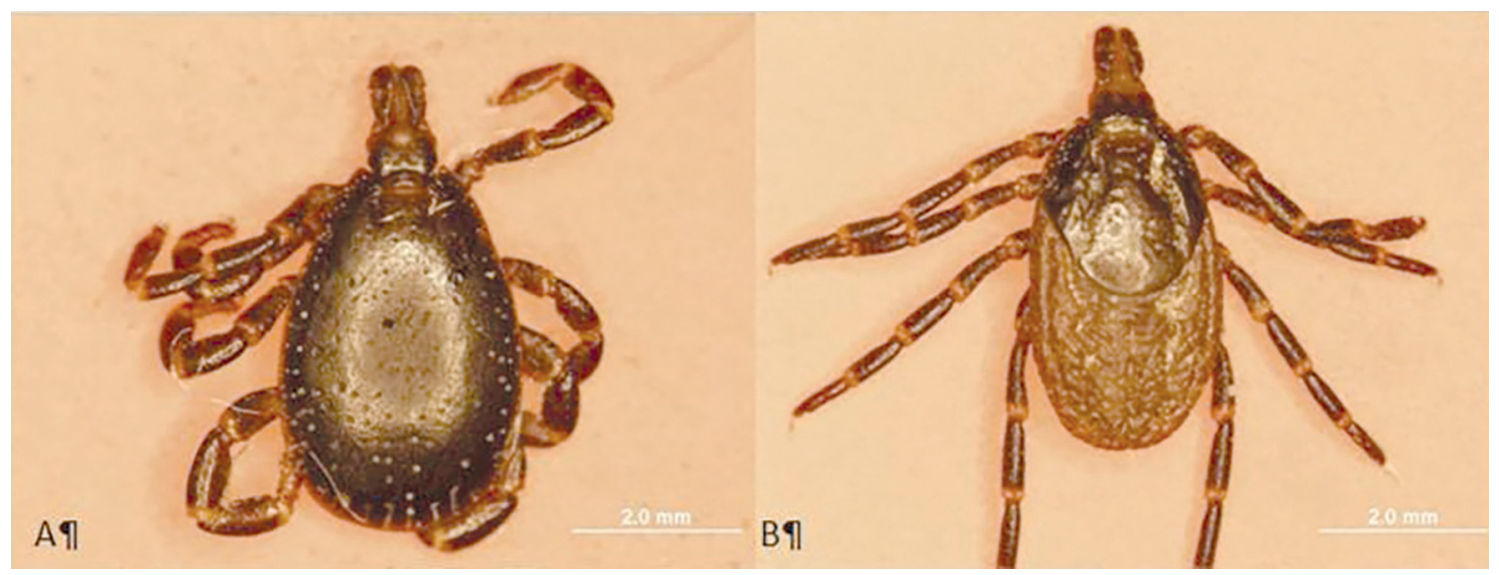

Figure 2. Hyalomma aegyptium male (A), Hyalomma aegyptium female (B)

Table 1. Distribution of Hyalomma aegyptium according to study area

\begin{tabular}{|c|c|c|c|c|c|}
\hline & \multicolumn{2}{|c|}{ İzmir } & \multicolumn{2}{|c|}{ Aydın } & \multirow[b]{2}{*}{ Prevalence $\%$} \\
\hline & $\hat{\sigma}$ & q & $\hat{\sigma}$ & $q$ & \\
\hline March & - & - & 11 & - & 4,8 \\
\hline May & 41 & 40 & 7 & 3 & 39,91 \\
\hline June & 32 & 9 & 28 & 12 & 35,53 \\
\hline July & 14 & 1 & 14 & 16 & 19,74 \\
\hline Total & 87 & 50 & 60 & 31 & 100 \\
\hline
\end{tabular}

\section{Discussion}

Hyalomma aegyptium is known as dominant species among ticks parasitizing tortoises in Mediterranean region, Northern Africa, Balkan countries, Pakistan, Russia, India, Middle East $[1,12,17,19]$, having a typical three-host life cycle. In Balkan countries and southern Europe the hosts of H.aegyptium are primarily tortoises but also lizards, dog, horse, hedgehog, cattle $[12,14,17]$. On the other hand the adult form H.aegyptium were reported from cattle and 
buffaloes from Balkan countries, Pakistan, Turkey, India $[2,5,12,19]$. While larvae and nymph forms of H.aegyptium mostly attack on partridges, lizards and a wide variety of rodents, the adults parasitize mainly on turtles $[1,6,17]$. The adult forms of H.aegyptium are also demonstrated to parasitize on humans $[6,11,15,20]$. In feeding, hosts of ticks and predilection sites on host body vary depending on tick species and instars $[6,15]$. In the present study, the predilection sites of H.aegyptium were mainly observed on hind limbs of tortoises and some were found on the neck.

Increasing number of human tick infestation rates raise the question about the importance of H.aegyptium as a vector of pathogens $[6,15,20]$. H.aegyptium threatens human health and animal production as they are shown to transmit pathogens like Borrelia burgdorferi, Theileria annulata, Pasteurella tularensis, Ricketsia aeschlimannii $[9,16,19]$. A spirochete, Borrelia turcica was also isolated from H.aegyptium collected from tortoises in Turkey [13].

In previous studies, H.aegyptium adults were reported from tortoises, lizards, hedgehog, cattle and human in Turkey $[2,4,6,12,16]$. Results obtained in this study, showed that H.aegyptium was the only tick species on tortoises in our study area. In previous studies, H.aegyptium, Haemaphysalis sulcata, H.inermis and Rhipicephalus sanguineus were reported from tortoises in Balkan countries [19]. Existence of eight different tick species belonging to three different genus on cattle has been demonstrated in Aydin province, in which H.aegyptium species could not be determined on cattle in Aydin province [7].

In conclusion, this study demonstrated the existence of H.aegyptium on tortoises in Aydin and Izmir provinces. However, in terms of determining the true prevalence of this tick on both tortoises and other animals and its potential role on transmitting diseases more studies need to be performed.

\section{References}

1. Apanaskevich DA, (2003) To diagnostics of Hyalomma aegyptium (Acari:Ixodidae). Parazitologiya. 37, 47-59.

2. Aydın L, (2000) Güney Marmara Bölgesi ruminantlarında görülen kene türleri ve yayılışları. Türkiye Parazitol Derg. 24, 194200 (article in Turkish with an English abstract).

3. Aydın L, Bakırcı S, (2007) Geographical distribution of ticks in Turkey. Parasitol Res. 101, 163 - 166.
4. Aydın L, Yıldırımhan HS, Uğurtaş İH, (2002) Marmara Bölgesi'ndeki bazı kertenkele ve kaplumbağa türlerinde kenelerin (Ixodidae) yaygınlığı. Türkiye Parazitol Derg. 26, 84-86 (article in Turkish with an English abstract).

5. Aysul, N, Kar S, Y1lmazer N, Alp HG, Garg1lı A, (2010) Trakya yöresi'ndeki Kaplumbağalarda (Testudo graeca) Hyalomma ae gyptium (Lıneaus, 1758)'un yaygınlığı. Pendik Vet Mikrobiyol Derg. 37(1), 53-56 (article in Turkish with an English abstract).

6. Bakırcı S, Aysul N, Eren H, Ünlü AH, Karagenç T, (2014) Diversity of ticks biting humans in Aydin Province of Turkey. Ankara Üniv Vet Fak Derg. 61, 93-98.

7. Bakırcı S, Sarali H, Aydın L, Eren H, Karagenç T, (2012) Distribution and seasonal activity of tick species on cattle in the West Aegean region of Turkey. Exp Appl Acarol. 56, 165178.

8. Bakırcı S, Sarali H, Aydın L, Latif A, Eren H, Karagenç T, (2011) Hyalomma rufipes (Koch, 1844) infesting cattle in the West Aegean region of Turkey. Turk J Vet Anim Sci. 35, 359-363.

9. Bitam I, Kernif T, Harrat Z, Parola P, Raoult D, (2009) First detection of Ricketsia aeschlimannii in Hyalomma aegyptium from Algeria. Clin Microbiol Infect. 15, 253-254.

10. Bursal1 A, Keskin A, Tekin S, (2012) A review of the ticks (Acari: Ixodidae) of Turkey: species diversity, hosts and geographical distribution. Exp Appl Acarol. 57, 91-104.

11. Gargılı A, Kar S, Yılmazer N, Cerit Ç, Sönmez G, Şahin F, Alp HG, Vatansever Z, (2010) Evoluation of ticks biting humans in Thrace province, Turkey. Kafkas Üniv Vet Fak Derg. 16, 141146.

12. Gazyağcı S, Aşan N, Demirbaş Y, (2010) A common tortoise tick, Hyalomma aegyptium Linne 1758 (Acari:Ixodidae), identified on eastern hedgehog (Erinaceus concolor Martin 1838) in Central Anatolia. Turk J Vet Anim Sci. 34, 211-213.

13. Guner ES, Hashimoto N, Kadosaka T, Imai Y, Masuzawa T, (2003) A novel, fast-growing Borrelia sp. isolated from the hard tick Hyalomma aegyptium in Turkey. Microbiology. 149 , 2539-2544.

14. Hoogstral H, (1956) African Ixodoidea. I. Ticks of the Sudan. U.S. Naval Medical Research Unit Cario, Egypt, No: 3, p: 513 516.

15. Kar S, Dervis E, Akın A, Ergonul O, Gargili A, (2013) Preferences of different tick species for human hosts in Turkey. Exp Appl Acarol. 61, 349-355.

16. Kireçci E, Özer A, Balkaya İ, Tanış H, Deveci S, (2013) Identification of ticks on tortoises (Tetudo graeca) and investigation of some pathogens in these ticks in Kahramanmaraş, Turkey. KSÜ Doğa Bil Derg. 16, 42-46.

17. Široký P, Erhart J, Petrzelková KJ, Kamler M, (2011) Life cycle of tortoise tick Hyalomma aegyptium under laboratory conditions. Exp Appl Acarol. 54, 277-284.

18. Široký P, Kubelová M, Modrý D, Erhart J, Literák I, Špitalská E, Kocianova E, (2010) Tortoise tick Hyalomma aegyptium as long term carrier of $\mathrm{Q}$ fever agent Coxiella burnetii-evidence from experimental infection. Parasitol Res. 107, 1515-1520

19. Široký P, Petrželková KJ, Kamler M, Mihalca AD, Modrý D, (2006) Hyalomma aegyptium as dominant tick in tortoises of the genus Testudo in Balkan countries, with notes on its host preferences. Exp Appl Acarol. 40, 279-290.

20. Vatansever Z, Gargili A, Aysul NS, Sengoz G, Estrada-Penã A, (2008) Ticks biting humans in the urban area of Istanbul Parasitol Res. 102,551-553. 